\title{
The Wealth Of Nations And Economic Governance, International Evidence
}

\author{
Ahmed Naciri. PhD. FCPA 1 \\ ESG Business School, University of Québec Montreal
}

\begin{abstract}
The paper suggests that wealth maximization and sustainability model (WMS) conforms to the basic maximization rule advocated by finance theory and they can therefore be dealt with within the same theoretical framework. A nation can develop and create wealth to the maximum of its potential only when it efficiently manages its development, i.e. when it observes the rule of national wealth maximization. Wealth is increasing unevenly around the world, as is the quality of living conditions. This prompts the following questions: What drives wealth maximization and sustainability (WMS), and how can it be made to last? To answer these two questions the paper suspects economic governance to impact tremendously wealth creation and accumulation, and tests its effect using a sample of 40 rich countries for the year 2019. It reveals important findings that make it possible to sketch a model of wealth maximization and sustainability.
\end{abstract}

Keywords: Wealth creation, wealth sustainability, public governance, rich countries

\section{THE WEALTH OF NATIONS AND ECONOMIC GOVERNANCE, INTERNATIONAL EVIDENCE}

A nation's wealth matters because wealth is a means to many ends, including having more choices in life as personal prosperity grows (Roser, 2019). Wealth is increasing unevenly around the world, as is the quality of living conditions. This prompts the following questions: What drives wealth maximization and sustainability2 (WMS), and how can it be made to last? Of the 7.4390 billion people living in the world in 2019, only 1.299 billion, or $18.44 \%$ of the global population live in rich economies. However they enjoy a $69.61 \%$ share of the world's wealth of USD317.064 billion, and they are getting richer at a higher rate. Although the complexity of development makes it difficult to fully analyze its nature and extent, we still can look for potential variables that can characterize wealth in rich environments. This paper tests the impact of economic governance on wealth creation and accumulation, using a sample of 40 rich countries for the year 2019. It reveals important findings and makes it possible to sketch a model of wealth maximization and sustainability.

\section{INTRODUCTION}

Current data on global wealth distribution, economic progress and wealth sharing indicates that the wealth maximization and sustainability model (WMS) conforms to the basic maximization rule suggested by finance theory and can therefore be dealt with within the same theoretical framework. A nation can develop and create wealth to the maximum of its potential only when it efficiently manages its development, i.e. when it observes the rule of national wealth maximization. The concept of national wealth used here extends financial considerations to encompass social wellbeing, as expressed through minimum requirements in the quality of education, health, sanitation, etc. According to the maximization rule, wealth is created and sustained and development occurs only when all development projects have social

\footnotetext{
${ }^{1}$ Ahmed Naciri is a professor at the ESG Business School in Montreal.

2 Maximization generally refers to the highest increase possible in wealth over an extended period.
} 
and/or financial net present values equal to zero or higher. Many governments seem unaware of this basic rule and of how much they owe or own or can invest in the public wellbeing. Such awareness would allow them to earn extra revenues of approximately 3 percent of GDP each year while reducing their risks (Gaspar and al., 2018). This achievement, however, is possible only in an environment of economic freedom, i.e. when citizens enjoy sufficient liberty to fully participate in national development. Under such conditions, national GDP is given a maximum chance to grow through individual and collective actions to undertake and embrace innovation and give life to individual dreams. Although achieving development is neither easy to conceive nor straightforward to operationalize, it remains a playable game, conditional on firm government commitment and its adoption of efficient behaviour to that end.

This paper assumes that government can be thought of as a diversified institution whose objective is to maximize the common wellbeing. Some specific governmental behaviour and attitudes seem to be crucial to any successful WMS endeavour; these are summarized in the paper under the term economic governance. It is assumed that economic governance can significantly explain why some countries have developed economically or are currently in the process of doing so. ${ }^{3}$

\section{DEFINING NATIONAL WEALTH}

National wealth can be defined as the sum of all the money, investments, goods, and property held in a country at a particular time. Wealth at the individual level can be defined as the aggregate of all the money, investments, goods, and property held by any citizen. Wealth plays a determining role in citizens' life and dictates the level of freedom they can enjoy in managing their affairs. In 2018, total global wealth topped \$317,065 billion (Credit Suisse, 2018). Following international practice, gross domestic product (GDP) is used in this paper to express wealth accumulation and economic development. A more accurate representation of people's living conditions begins, however, with dividing a nation's GDP by the number of people who live there, resulting in a figure called per capita GDP, or pcGDP. The pcGDP and its growth rate, $\Delta$ pcGDP, tell us much more about the wealth potentially available to each person and whether this wealth is either increasing or decreasing over time. pcGDP can therefore be used to assess the performance of the WMS model. Practically, the GDP is commonly expressed as the sum of the value added by all resident producers, plus any product taxes (minus subsidies) not included in the valuation of output (World Bank, 2015). Depending on availability of data, gross national income (GNI) is occasionally referred to and is expressed as the total income generated by domestic production, including income from trade. ${ }^{4}$ While GDP is commonly considered to be the single most important indicator for capturing economic activity, it may, however, fall short of providing a suitable measure of people's material wellbeing, for which alternative indicators may be more appropriate.

This is why looking at the pcGDP would be a more accurate way to assess this activity. For instance, a high pcGDP could be offset by high cost of living, leaving citizens not as well off as they could be. Without a measure of wealth distribution among citizens, it is difficult to assess their real individual wellbeing. The world's richest 1 percent, those with more than $\$ 1$ million, for instance, own 45 percent of the world's wealth (Credit Suisse, 2018). Measured on the basis

\footnotetext{
${ }^{3}$ While there may be many answers to these questions, the paper outlines one possible explanation that, if true, has strong implications for nations' wealth accumulation and economic development today.

${ }^{4}$ Actually the World Bank uses the Gross National Income, GNI for its classification, the GDP and the GNI measures diverge only slightly, as the GNI is simply the GDP increased by the balance of primary income flows from the rest of the world. The GNI is therefore equal to GDP plus BPI, usually defined as household incomes from direct and indirect economic activity, excluding social benefits.
} 
of purchasing power parity, or PPP, the GDP is considered to be acceptable for comparisons between economies, and it decreases bias in economic estimations since PPP takes into account the relative cost of local goods and services and the country's inflation rates. As of July 2019, the World Bank considers a rich country to be any economy that has a GDP per capita of $\$ 12,376$ or greater. The other groups of economies are upper middle-income, with a GDP between 3,996 and 12,375; lower middle-income, with a GDP between 1,026 and 3,995; and low-income, with a GDP lower than 1,026 (blogs.worldbank.org). Because pcGDP is simply GDP divided by the population, it measures income as though divided equally among the population. In reality, there can be wide variations in the incomes of people within a country. Therefore even in a country with a relatively low GDP, some people are better off than others (Wolla, 2017). One good news, however, the World Bank seems to have taken up recently the case for a basic income (Gentilini et al., 2020). Although, this is not a panacea, economic security can renew economy (Stern, 2016) and if this is the case this will can an anchor of 21st century income distribution. (Standing, 2017). Although one can wonder how such seemingly utopian proposal of providing cash unconditionally to everyone can succeed? (Gentilini et al., 2020).

\begin{tabular}{|c|c|c|c|c|c|c|}
\hline Country & $\begin{array}{l}\text { Population } \\
(000)\end{array}$ & $\begin{array}{l}\text { Population } \\
\%\end{array}$ & $\begin{array}{l}\text { Total } \\
\text { Wealth } \\
\text { USD billion }\end{array}$ & $\begin{array}{l}\text { Total } \\
\text { Wealth } \\
\%\end{array}$ & $\begin{array}{l}\text { Mean } \\
\text { Wealth per } \\
\text { Adult USD }\end{array}$ & $\begin{array}{l}\text { Mean } \\
\text { Wealth per } \\
\text { Adult \% }\end{array}$ \\
\hline Africa & $1,258,783$ & 17 & 2,553 & 1 & 4,138 & 7 \\
\hline Asia-Pacific & $1,806,696$ & 24 & 56,715 & 18 & 48,119 & 76 \\
\hline China & $1,412,282$ & 19 & 51,874 & 16 & 47,810 & 76 \\
\hline Europe & 745,345 & 10 & 85,402 & 27 & 144,903 & 230 \\
\hline India & $1,346,616$ & 18 & 5,972 & 2 & 7,024 & 11 \\
\hline Latin America & 648,436 & 9 & 8,055 & 3 & 18,605 & 29 \\
\hline North America & 362,538 & 5 & 106,613 & 34 & 391,610 & 630 \\
\hline World & $7,579,695$ & 100 & 317,064 & 100 & 63,100 & 100 \\
\hline
\end{tabular}

Source: Adapted from: Credit Suisse (2018).

North America and Europe share $61 \%$ of the world's wealth, or $\$ 106,613$ billion, out of $\$ 317,064$ billion. Asia-Pacific and China enjoy $34 \%$ of this total share, or $\$ 108,000$ billion, while the rest of the world shares the remaining 6\% as follows: Africa 1\%, India 2\% and Latin America 3\%. As for individual data, Table 3, Column 7 indicates that a North American adult enjoys wealth equivalent to $630 \%$ of the world average, and 90 times the wealth of an African adult. The overall desirable situation would be "convergence" between world economies. Poor economies should grow more rapidly and eventually achieve the level of prosperity of rich economies, but this would be possible only if good economic policies are adopted, as in the case of countries like Singapore and South Korea. History generally shows that economic growth allows population growth and rising prosperity to go hand in hand (Roser, 2019).

\section{ECONOMIC GOVERNANCE}

As economic governance appears essential to WMS, it is defined in this paper as the set of actions to be taken by a government in order to maximize and sustain national wealth. WMS is the responsibility of every government, and all governments must do all they can toward this objective. Governments are considered to behave according to good economic governance rules. It is reasonable to expect nations to maximize their wealth when they efficiently manage their resources. However, the national wealth maximization rule requires a specific economic setting, one that allows citizens to enjoy economic freedom in a way that permits them to participate fully in national wealth creation and accumulation, i.e. maximizing national GDP. In such a situation, citizens are expected to enjoy easy access to opportunities and to face only few barriers and irritants that may reduce their ability to innovate and exercise their 
entrepreneurial capacity and skill (World Bank, 2017a). Many nations go about the process in the wrong way when, for political considerations, they impose a great many barriers on citizens on the road to entrepreneurship, aiming to block them from accessing wealth, usually for the benefit of a small dominant class. By doing so, they are actually denying a large portion of their population the freedom to live decently.

Most rich economies seem to share one common capability, i.e. facilitating access to wealth for most of their citizens. The assurance of having access to wealth generally occurs under two main conditions. First, citizens are encouraged to engage in wealth creation activities when their government invests sufficiently in key sectors of wealth creation and value-added projects such as education and training, sanitation, infrastructure and the like, while overcoming the sizeable constraint of convincing their citizens to abide by their laws, particularly tax laws. This is usually possible only when governments conduct themselves appropriately and demonstrate credible, consistent and fair application of their laws (World Bank, 2017). This also enables public institutions to operate at acceptable levels of fairness and efficiency. As a result, wealth-creating nations usually enjoy easy access to adequate local financing through tax collection, and can eventually turn to the international debt market whenever extra funds are still needed (Naciri, 2018). As a rule, wealth-creating economies commonly have a sufficient and effective income collection system, coupled with a fair and efficient public expenditure system, which are geared to protecting citizens against the vagaries of life while shielding them through appropriate policies that reduce social disparities (World Bank, 2017).

Second, citizens will also engage in wealth-creation activities when their government adopts productive economic governance rules ${ }^{5}$ based on the concept of economic freedom and selfownership. This is a scenario in which individuals have the right to choose and decide how to use their time, money and talents to shape their lives and their nation's economy. Economic governance has several foundational principles such as personal choice, voluntary exchange, open markets, and clearly defined and enforced property rights. Individuals are considered "to be economically free when they are permitted to choose for themselves and engage in voluntary transactions as long as they do not harm the person or property of others" (Fraser Institute, 2017). Critics have, however, contested the assumption that economic governance necessarily leads to more wealth creation. As examples, they have pointed out that some countries recognized for their good economic governance rating, such as Uruguay, had sluggish wealth creation performances, while others known for poorer economic governance ratings, like China, had very strong wealth growth (Sachs, 2006). It may make sense to affirm, however, that once citizens are permitted to expand and explore the breadth of their potential, domestic human and material resources industries will be better used and local authorities will work more effectively toward national wealth creation.

It is rational to expect, at least in theory, that economic governance should foster wealth growth, and for multiple reasons (The Heritage Foundation, 2017). One common reason is that "nations with higher degrees of economic freedom prosper" (Index of Economic Freedom), mainly because that they tend to capitalize more fully on the knowledge and ability of all individuals in their societies. Another reason is that "the free-market system provides a framework for organizing, without coercion, the skills, talents, and effort of individuals toward the production of the goods and services most in demand by their fellow citizens" (The

5 These nations are expected to grow economically, especially once adequately trained, and when healthy generations have accessed employment in adulthood and can thus contribute efficiently to the common wellbeing of their nation. 
Heritage Foundation, 2017) Lastly, economic governance is supposed to generate dynamic economic growth for society as a whole and promote innovation through the efficient allocation of resources (The Heritage Foundation, 2017).

Governments that ensure economic freedom for their citizens are therefore reasonably expected to be in a position to provide a high level of economic governance even though investment in economic governance can be slow to produce the anticipated returns (World Bank, 2017). The paper assesses the impact of economic governance on WMS on two factors: (i) on wealth maximization, as expressed by the rate of increase/decrease of the pcGDP; and (ii) in terms of wealth sustainability as expressed by pcGDP. Null hypotheses H0s can therefore be set as: Economic openness has no effect on a nation's wealth sustainability, and economic governance has no effect on a nation's wealth maximization.

\section{SAMPLE DATA AND METHODOLOGY}

Economic governance is based on a specific scenario whereby individuals are given the right to choose and to decide for themselves how to shape their own lives and use their time, talents and resources. Attempts have been made to measure the degree of economic governance in the world. One recognized assessment is the Index of Economic Freedom (IEF), ${ }^{6}$ developed by The Heritage Foundation and The Wall Street Journal. This index is highly suitable for our study and will therefore be used to approximate economic governance. The economic governance model can be decomposed into 12 individual components that governments must provide their citizens if wealth creation is to be achieved. A country can maximize its economic governance when its 12 components of economic openness are also maximized. In other words, when:

- Property rights, or PR, are respected; this is when the government makes sure the country's legal system effectively allows individuals to freely accumulate private property, and protects them against any misappropriation;

- Judicial effectiveness, or JE, is ensured, as it is essential for protecting the rights of all citizens against the unlawful behaviour of powerful parties. Economic value is created by the efficient allocation of an economy's capital to a small number of very wealthy families. This could be desirable only if these families provided optimal management of wealth (Morck et al.,1998). The rule of law is usually undergirded by a societal intolerance of corruption (Index of Economic Freedom-2019). ${ }^{7}$

- Government integrity, or GI, is ensured by curbing corruption. Corruption can seriously jeopardize economic vitality by increasing costs and shifting resources to unproductive lobbying activities, thus diverting them from national wealth creation;

- Tax Burden, or Tb, should be minimized for citizens by setting the amount of tax paid by citizens in a specified period to a bearable proportion of total income in that period;

- Government spending, or GS, should be an optimized amount achieved by curbing spending. This requires using restraint in order to avoid burdening the national budget;

- Fiscal health, or FH, should be guaranteed by opting for policies, procedures and controls to protect financial and economic resources and ensure they are used for citizens' interests;

- Governments should maintain open market conditions by establishing and ensuring economic freedoms. These freedoms are:

(i) Business freedom, or BF, i.e. setting conditions and using methods that make regulatory and infrastructure environments attractive for the efficient operation of businesses.

\footnotetext{
${ }^{6}$ The other index is the Economic Freedom of the World (EFW), originally developed by the Fraser Institute.

7 https://www.heritage.org/index/country/singapore
} 
(ii) Labour freedom, or LF, which results from acting on various aspects of the legal and regulatory framework of a country's labour market, including regulations concerning minimum wages, the prevention of layoffs, and severance requirements.

(iii) Monetary freedom, or MF, which is achieved by combining measures of price stability with an assessment of price controls. Both inflation and price controls distort market activity. Price stability without government intervention can be the ideal state for the free market;

(iv) Trade freedom, or TF, obtained by eliminating barriers that affect imports and exports of goods and services;

(v) Investment freedom, or IF, resulting from constraints on the flow of investment capital;

(vi) Financial freedom, or FF, achieved by ensuring the efficiency of financial institutions and granting a measure of independence from government control and interference in the financial sector.

The purpose of economic governance is to give people incentives not only to enrich themselves but also to continually improve their wealth. This cannot occur if citizens are not rewarded for their efforts, or if the benefits of their work are likely to be taken away or lost, causing their desire to create wealth to diminish (Wolla, 2017). The current study, which aims to assess the economic freedom given to the citizens of rich countries, was conducted on the populations of all wealthy countries with an accessible pcGDP and economic governance scores. Appendix A lists the wealthy countries that conform to the World Bank's 2019 definition and for which data on pcGDP and component scores of economic freedom ${ }^{8}$ are available. There should be therefore no size effect.

This paper seeks to discover how the quality of the economic governance of rich countries may explain their economic performance. Economies that have the good fortune of owning major oil fields, i.e. rich countries whose wealth is significantly due to oil exportation, are excluded from the sample. ${ }^{9}$ Using regression analysis, the study highlights economic determinants of wealth maximization through the country's pcGDP on a purchasing power parity (PPP) basis, and wealth sustainability through the country's five-year mean increase in pcGDP, $\triangle 5 y$ pcGDP, also on a PPP basis. The study is conducted for the year 2018. Data were collected from several notable sources:

- Data on pcGDP were retrieved from the World Factbook for the year 2018.10 The pcGDP is commonly used to measure a country's economic progress and is defined as the GDP on a purchasing power parity basis, divided by the population as of 1 July of that same year.

The page located at https://knoema.fr/pjeqzh/gdp-per-capita-by-country-statisticsfrom-imf- provides access to pcGDP data based on PPP. Given the disparity of countries' pcGDP, log of pcGDP was used (log pcGDP).

- Data on the five-year mean increase in pcGDP ( $\triangle 5 y$ pcGDP) were retrieved from the World Factbook.

\footnotetext{
8 Countries missing from the sample include Burma, Dominica, Grenada, Kiribati, Libya, Macau, Saint Lucia, Saint Vincent and the Grenadines, South Sudan, Syria, Tonga, Vanuatu and Yemen.

9 These are Bahrain, Chile, Kuwait, Qatar, Saudi Arabia and the United Arab Emirates.

10 The World Factbook provides information on the history, people, governments, economy, geography, communications, transportation, military and transnational issues of 267 world entities.
} 
- Data on countries' economic governance components were retrieved from the Index of Economic Freedom (IEF), developed by The Heritage Foundation and The Wall Street Journal, for the year 2018.11

As discussed, pcGDP may not fully capture a nation's wealth or reflect a population's wellbeing when a measure of its dispersion is missing, which is the case with international data. This is also the case whenever pcGDP does not account for extractive effects such as pollution. Two things are clear, however: wealth inequality is negatively associated with cross-country economic growth (Islam et al., 2019), and "having money from economic growth flow also to poor people feeds into a lift in the rate of economic growth" (Koukoulas, 2015). Consequently, it is reasonable to assume that the greater a country's ability to create wealth, the narrower the dispersion of its pcGDP will be. To investigate which components of economic governance explain wealth creation, ordinary least square regressions are run on the data. To assess the sustainability of wealth, regression E.1 is run to describe the statistical relationship between the log of pcGDP on a PPP basis, or pcGDP $_{i}$, between a nation and the quality of its economic governance.

$\log \left(\mathrm{pcGDP}_{\mathrm{i}}\right)=\alpha+\beta_{1} \mathrm{SG}_{\mathrm{i}+} \beta_{2} \mathrm{PR}_{\mathrm{i}+} \beta_{3} J \mathrm{E}_{+} \beta_{4} \mathrm{GI}_{\mathrm{i}}+\beta_{5} \mathrm{~TB}_{+} \beta_{6} \mathrm{GS}_{\mathrm{i}}+\beta_{7 \mathrm{i}+} \beta_{7} \mathrm{FH}_{\mathrm{i}}+\beta_{8} \mathrm{BF}_{\mathrm{i}+} \beta_{9} \mathrm{LF}_{\mathrm{i}}+\beta_{10} \mathrm{MF}_{\mathrm{i}}+\beta_{11} \mathrm{TF}_{\mathrm{i}}+$ $\beta_{12} \mathrm{IF}_{\mathrm{i}}+\beta_{13} \mathrm{FF}_{\mathrm{I}}+\varepsilon$

E. 1

To assess the maximization of wealth, regression E.2 is run to describe the statistical relationship between the five-year growth of an economy's pcGDP on a PPP basis, or $\Delta 5 y$ pcGDP.

$\Delta 5 y$ pcGDP $=\alpha+\beta_{1} \mathrm{SG}_{\mathrm{i}+} \beta_{2} \mathrm{PR}_{\mathrm{i}+} \quad \beta_{3} \mathrm{JE}_{+} \beta_{4} \mathrm{GI}_{\mathrm{i}}+\beta_{5} \mathrm{~TB}_{+} \beta_{6} \mathrm{GS}_{\mathrm{i}}+\beta_{7 \mathrm{i}+} \beta_{7} \mathrm{FH}_{\mathrm{i}}+\beta_{8} \mathrm{BF}_{\mathrm{i}+} \beta_{9} \mathrm{LF}_{\mathrm{i}}+\beta_{10} \mathrm{MF}_{\mathrm{i}}+\beta_{11} \mathrm{TF}_{\mathrm{i}}+$ $\beta_{12} \mathrm{IF}_{\mathrm{i}}+\beta_{13} \mathrm{FF}_{\mathrm{I}}+\varepsilon$

E. 2

Where variables in E.1 and E.2 are as defined previously; pcGDP is per capita GDP on a purchasing power parity basis; $\Delta 5 y$ pcGDP is the five-year average variation in $\mathrm{pcGDP}_{\mathrm{i}}$ on a purchasing power parity basis; and PR is Property Rights; JE, Judicial Effectiveness; GI, Government Integrity; TB, Tax Burden; GS, Government Spending; FH, Fiscal Health; BF, Business Freedom; LF, Labor Freedom; MF, Monetary Freedom; TF, Trade Freedom; IF, Investment Freedom; and FF, Financial Freedom.

The correlation is assessed between individual components of economic governance. In case of low correlation between components, we assess the contribution of individual components of economic governance to the overall index, Economic Governance, or EG. For this purpose, we run an additional regression:

$\mathrm{EG}_{\mathrm{i}}=\alpha+\beta_{1} \mathrm{SG}_{\mathrm{i}+} \beta_{2} \mathrm{PR}_{\mathrm{i}+} \beta_{3} \mathrm{JE}_{+} \beta_{4} \mathrm{GI}_{\mathrm{i}}+\beta_{5} \mathrm{~TB}_{+} \beta_{6} \mathrm{GS}_{\mathrm{i}}+\beta_{7 \mathrm{i}+} \beta_{7} \mathrm{FH}_{\mathrm{i}}+\beta_{8} \mathrm{BF}_{\mathrm{i}+} \beta_{9} \mathrm{LF}_{\mathrm{i}}+\beta_{10} \mathrm{MF}_{\mathrm{i}}+\beta_{11} \mathrm{TF}_{\mathrm{i}}+\beta_{12} \mathrm{IF}_{\mathrm{i}}+\beta_{13}$ $\mathrm{FF}_{\mathrm{I}}+\varepsilon$

E.3

Where $\mathrm{EG}_{\mathrm{i}}$ is overall economic governance, as defined by the Index of Economic Freedom , developed by The Heritage Foundation and The Wall Street Journal, while the other variables are as defined previously. 


\section{RESULTS}

Table 2 provides descriptive statistics for the variables used in the study. The highest wealthy country pcGDP of $\$ 106,374^{12}$ was recorded by Ireland in 2018 , while the lowest, $\$ 16,660$, was recorded by China.

Table 2: Descriptive Statistics, Rich Country Sample

$\begin{array}{llll} & \text { Mean } & \text { Standard Deviation } & \mathrm{N} \\ \log (\text { pcGDP }) & 4.7500 & .43853 & 40 \\ \Delta 5 y \text { pcGDP } & 2.4575 & 1.94210 & 40 \\ \text { Property Rights } & 76.8800 & 11.37868 & 40 \\ \text { Judicial Effectiveness } & 64.6500 & 15.28789 & 40 \\ \text { Government Integrity } & 65.5225 & 19.71297 & 40 \\ \text { Tax Burden } & 66.9825 & 11.88515 & 40 \\ \text { Government Spending } & 47.7850 & 21.11202 & 40 \\ \text { Fiscal Health } & 82.5425 & 16.88316 & 40 \\ \text { Business Freedom } & 77.6575 & 9.89032 & 40 \\ \text { Labour Freedom } & 64.3925 & 12.81908 & 40 \\ \text { Monetary Freedom } & 81.6750 & 3.99665 & 40 \\ \text { Trade Freedom } & 84.9650 & 4.38690 & 40 \\ \text { Investment Freedom } & 78.6250 & 12.45440 & 40 \\ \text { Financial Freedom } & 67.2500 & 14.32006 & 40\end{array}$

Given the high dispersion of the pcGDP among rich economies, using the logarithm of pcGDP $(\log ($ pcGDP) $)$ seems more appropriate. The mean value of the $\log$ (pcGDP) of 4.75 has a standard deviation of .48. The five-year mean increase in pcGDP ( $\triangle 5 y$ pcGDP) was $2.4575 \%$, with a standard deviation of $1.942 \%$. On average, rich countries received high economic governance scores, i.e. 84.96 on a scale of 1 to 100 ( 1 being the lowest and 100 the highest) for Trade Freedom, 82.54 for Fiscal Health, 81.67 for Monetary Freedom, and 78.62 for Investment Freedom, but only 67.25 for Financial Freedom. Disparities within countries are located within the $15 \%$ range, except for Government Spending at $21.11 \%$, Government Integrity at $19.71 \%$, Fiscal Health at $16.88 \%$ and Judicial Effectiveness at $15.29 \%$.

Table 3 gives the model summary for regressions E. 1 where $\log$ (pcGDP) is set as the dependent variable. The overall regression model is highly significant at the 0.000 level. As indicated by the R-Squared of .707, with an adjusted R-Squared of .576, a large measure of country pcGDP variability can be explained by the quality of countries' economic governance. As this latter factor explains $70.07 \%$ of wealth sustainability, our alternative hypothesis is confirmed.

Table 3: Statistical Summary, Regression E.1

$\begin{array}{ccccccccc}\text { R } & \text { R-Squared } & \begin{array}{c}\text { Adjusted } \\ \text { R-Squared }\end{array} & \begin{array}{c}\text { Standard Error } \\ \text { of Estimate }\end{array} & \begin{array}{c}\text { Change } \\ \text { Statistics } \\ \text { R-Squared } \\ \text { Change }\end{array} & \text { F Change } & \text { df1 } & \text { df2 } & \begin{array}{c}\text { Sig. F } \\ \text { change }\end{array} \\ .841 \mathrm{a} & .707 & .576 & .28552 & .707 & 5.417 & 12 & 27 & .000\end{array}$

a Predictor: (Constant), Property Rights, Judicial Effectiveness, Government Integrity, Tax Burden, Government Spending, Fiscal Health, Business Freedom, Labour Freedom, Monetary Freedom, Investment Freedom, Financial Freedom.

\footnotetext{
${ }^{12}$ Ireland's pcGDP is nonetheless lower than Qatar's pcGDP of $\$ 124,529$. However, Qatar was not included in the sample, given that it is an oil exporter.
} 
Table 4 gives the model summary for regression E.2, where $\Delta 5 y$ pcGDP is set as the dependent variable. As indicated by the R-Squared of .483 and an Adjusted R-Squared of .253, the overall regression model shows that a significant proportion of the variability in the country five-year increase in pcGDP ( $\Delta 5 y$ pcGDP) can also be explained by the quality of its economic governance, with is significant at 0.053 . This result confirms our second alternative hypothesis and indicates that quality of economic governance can explain $48.30 \%$ of wealth maximization.

$\log \left(\mathrm{pcGDP}_{\mathrm{i}}\right)=\alpha+\beta_{1} \mathrm{SG}_{\mathrm{i}+} \beta_{2} \mathrm{PR}_{\mathrm{i}+} \beta_{3} \mathrm{JE}_{+} \beta_{4} \mathrm{GI}_{\mathrm{i}}+\beta_{5} \mathrm{~TB}_{+} \beta_{6} \mathrm{GS}_{\mathrm{i}}+\beta_{7 \mathrm{i}+} \beta_{7} \mathrm{FH}_{\mathrm{i}}+\beta_{8} \mathrm{BF}_{\mathrm{i}+} \beta_{9} \mathrm{LF}_{\mathrm{i}}+\beta_{10} \mathrm{MF}_{\mathrm{i}}+\beta_{11} \mathrm{TF}_{\mathrm{i}}+$ $\beta_{12} \mathrm{IF}_{\mathrm{i}}+\beta_{13} \mathrm{FF}_{\mathrm{I}}+\varepsilon$

Table 4: Statistical Summary, Regression E.2

$\begin{array}{ccccccccc}\text { R } & \text { R-Squared } & \begin{array}{c}\text { Adjusted } \\ \text { R-Squared }\end{array} & \begin{array}{c}\text { Standard Error } \\ \text { of Estimate }\end{array} & \begin{array}{c}\text { Change } \\ \text { Statistics } \\ \text { R-Squared } \\ \text { Change }\end{array} & \begin{array}{c}\text { F } \\ \text { Change }\end{array} & \text { df1 } & \text { df2 } & \begin{array}{c}\text { Sig. F } \\ \text { Change }\end{array} \\ .695 a & .483 & .253 & 1.67816 & .483 & 2.103 & 12 & 27 & .053\end{array}$

a Predictor: (Constant), Property Rights, Judicial Effectiveness, Government Integrity, Tax Burden, Government Spending, Fiscal Health, Business Freedom, Labour Freedom, Monetary Freedom, Investment Freedom, Financial Freedom.

Table 5 underlines the correlation between the 12 components of economic governance. A correlation coefficient of $\mathbf{0 . 6 / - 0 . 6}$ is considered a significantly moderate positive/negative relationship. There are only three significant correlations between the 12 components of economic governance: Government Spending is $-68.3 \%$ correlated to Tax Burden, Tax Burden is $-68.3 \%$ correlated to Government Spending, and Government Integrity is $-76.1 \%$ correlated to Judicial Effectiveness.

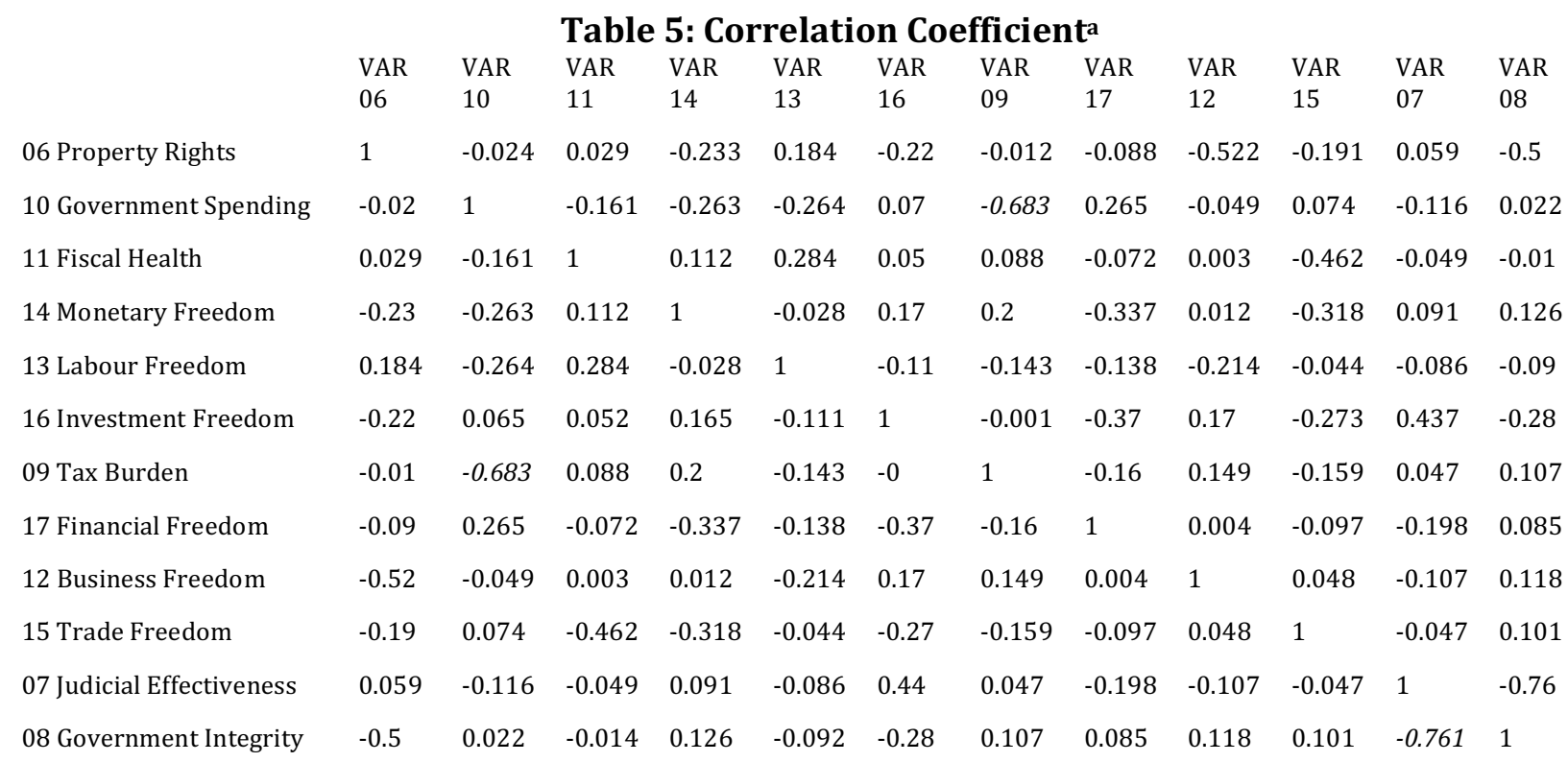

a Dependent variable: pcGDP, yielding moderate correlations

The correlation analysis finds almost no significant correlation between components of economic governance, which means that in order for a country to score well on economic governance, it must pay attention to all 12 of the components. These components may be expressed in various units or scales; to address this methodological problem, we focus on standardized beta coefficients, allowing the assessment of the relative weight of each 
component. To assess the contribution of each component to overall economic governance, regression E.3 was run.

In Table 6, the individual contribution of components is measured by the standardized beta, and as expected, E.3 displays an R and R-Squared of $1 .^{13}$ Impacts on economic governance by individual components expressed in various units or scales are measured through standardized beta coefficients, allowing the relative weight of each coefficient in the regression model to be compared. This impact varies between $5 \%$ and $24 \%$. Once classified by the size of its impact on overall economic governance, Government Spending appears to be the most impactful, explaining $24 \%$ of all of economic governance behaviour, followed by Government Integrity at $22.6 \%$, Fiscal Health at $19 \%$, and so forth. All standardized betas are highly significant at $\mathrm{p}=.000$.

$\begin{array}{lccccc} & \begin{array}{c}\text { Non- } \\ \text { Standardized } \\ \text { Coefficients }\end{array} & & \begin{array}{c}\text { Standardized } \\ \text { Coefficients }\end{array} & \mathrm{T} & \text { Sig. } \\ & \mathrm{B} & \begin{array}{c}\text { Standard } \\ \text { Error }\end{array} & \text { Beta } & & \\ \text { (Constant) } & .184 & .149 & & 1.229 & .230 \\ \text { Business Freedom } & .082 & .001 & .110 & 97.546 & .000 \\ \text { Financial Freedom } & .084 & .001 & .163 & 142.811 & .000 \\ \text { Fiscal Health } & .083 & .000 & .190 & 224.423 & .000 \\ \text { Government Integrity } & .085 & .001 & .226 & 100.250 & .000 \\ \text { Government Spending } & .084 & .000 & .240 & 214.683 & .000 \\ \text { Investment Freedom } & .082 & .001 & .139 & 123.572 & .000 \\ \text { Judicial Effectiveness } & .081 & .001 & .169 & 92.313 & .000 \\ \text { Labour Freedom } & .083 & .001 & .144 & 164.355 & .000 \\ \text { Monetary Freedom } & .083 & .002 & .045 & 47.160 & .000 \\ \text { Property Rights } & .084 & .001 & .130 & 66.342 & .000 \\ \text { Tax Burden } & .082 & .001 & .133 & 120.899 & .000 \\ \text { Trade Freedom } & .083 & .002 & .050 & 42.224 & .000\end{array}$

a Dependent variable $=\mathrm{EG}($ economic governance $)$

\section{DISCUSSION OF RESULTS}

Singapore, Hong Kong, Taiwan and South Korea (East Asian economies) are living examples of how economic governance leads to economic development and wealth creation. Figure 1 compares the economic governance of these four East Asian economies with averages for rich countries.

\footnotetext{
13 Model Summary of E.3

Model $\quad \mathrm{R}$

R R-Squared Adjusted R-

Squared

$1.000 \mathrm{a}$

1.000

1.000

Standard Error of the Estimate

1

a Predictor: (Constant), VAR00006, VAR00010, VAR00011, VAR00014, VAR00013, VAR00016, VAR00009, VAR00017,

VAR00012, VAR00015, VAR00007, VAR00008
} 


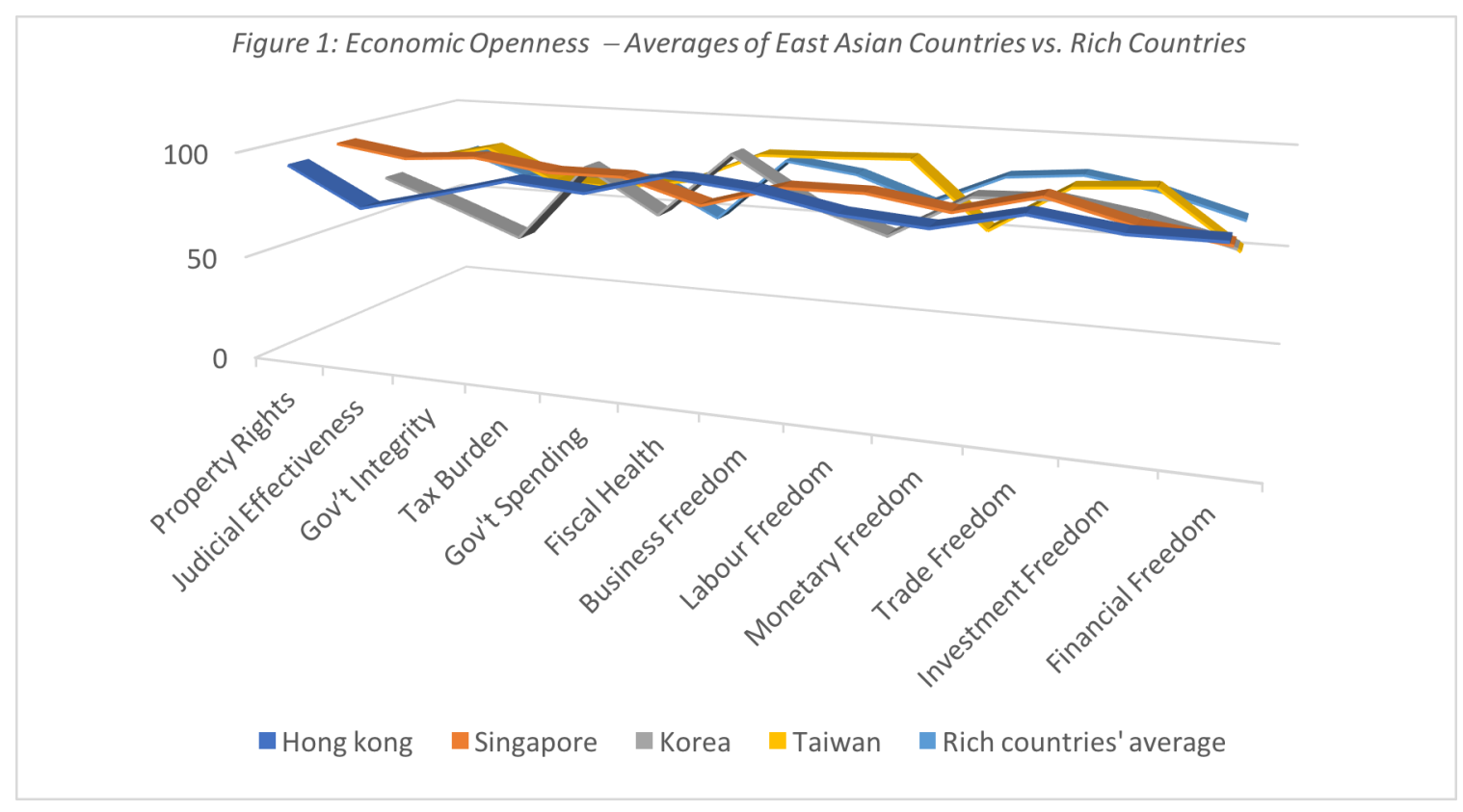

Data show that the four East Asian countries' per capita income peaked at more than $100 \%$ of the rich countries' average and outperformed their average economic governance in most areas, except government integrity, in South Korea, and monetary freedom, in Taiwan. Singapore outperformed all other East Asian economies except in fiscal health. With a pcGDP of $\$ 102,352.86$ in 2018, Singapore outperformed the average GDP of all rich countries by $\$ 59,735.00$, and stands as a perfect example of WMS through the enhancement of economic governance. This shows that the world is no more the zero-sum economy it used to be and one person's or one country's gain is not automatically another one's loss (Roser, 2019b). This also helps to sketch a WMS model that is worth following. "Until recently, Singapore was confronted with severe unemployment, poor infrastructure and a housing shortage. Today the "city-state" is ranked as one of the most liveable cities, boasting one [of] the highest levels of human capital development. Recently, Singapore was even ranked the best country in the world for human capital development."14 Singapore's economic growth has been among the world's highest.15 Figure 2 compares Singapore's economic governance performance to the average for rich economies.

\footnotetext{
${ }^{14}$ https://www.worldbank.org/en/country/singapore/overview; World Bank Human Capital Index,

15 Singapore has enjoyed average economic governance growth of $7.7 \%$ since independence, which even topped $9.2 \%$ in the first 25 years. In the early 1970s, Singapore reached full employment and joined the ranks of Hong Kong, South Korea and Taiwan a decade later as Asia's newly industrializing countries. https://www.worldbank.org/en/country/singapore/overview
} 


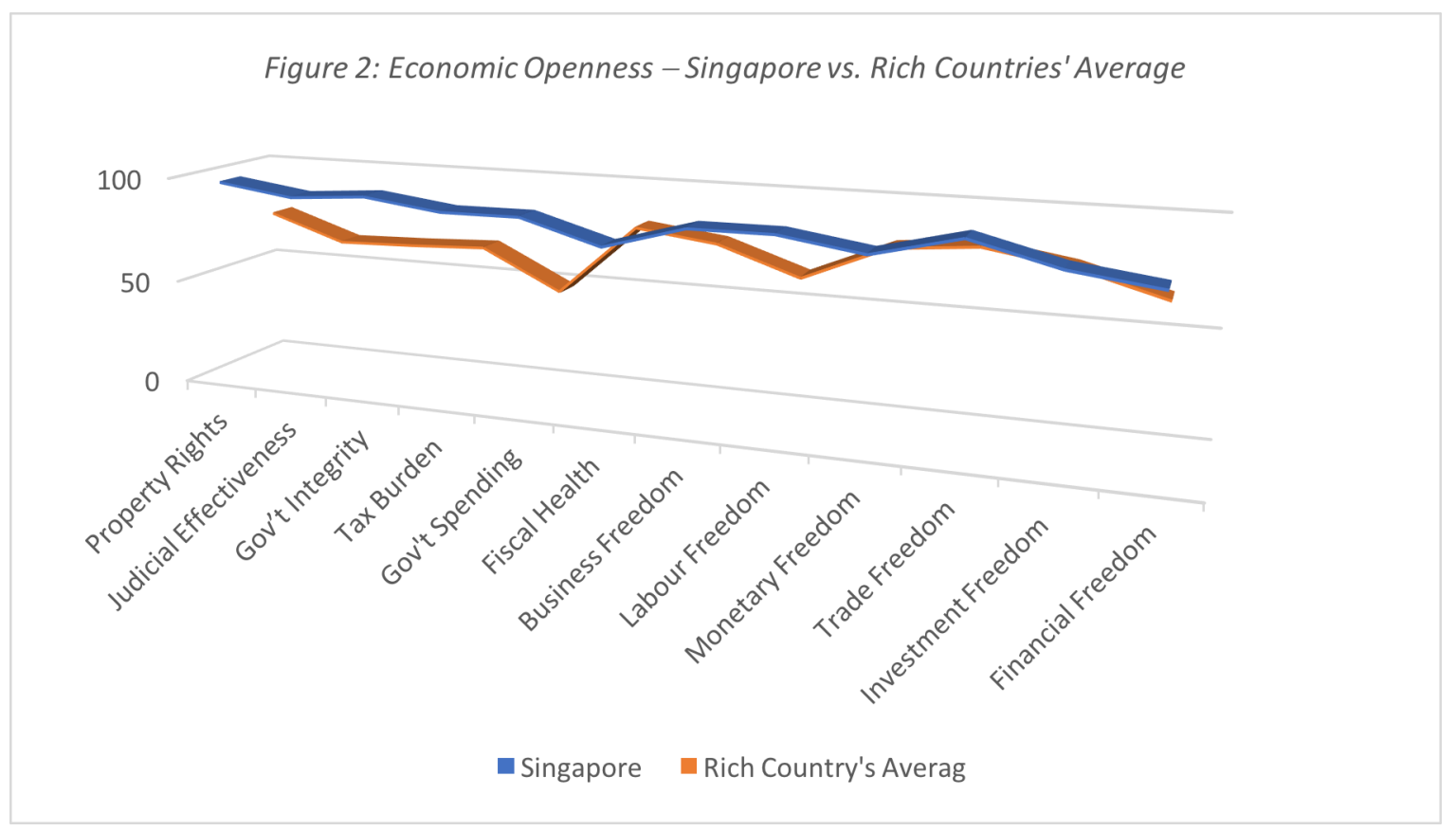

Singapore outperformed the wealthy countries' average for every economic governance component except for fiscal health, which is nonetheless comparable to the rich countries' average. This outstanding performance ranges from an additional $44 \%$ for government spending to $5 \%$ for monetary freedom. Further, property rights has a $22 \%$ advantage in Singapore over the rich countries' average; the judicial system is $29 \%$ more effective; government integrity is $31 \%$ greater; the tax system is $25 \%$ less oppressive; and fiscal health is comparable. Singapore clearly outstrips wealthy countries in every aspect of economic freedom-business, labour, monetary, trade, investment and financial. Singapore appears to maximize its citizens' chances of performing effectively in life, more so than average citizens in rich countries. It therefore appears that "Singapore owes its success as a highly developed freemarket economy in large part to its remarkably open and corruption-free business environment, prudent monetary and fiscal policies and transparent legal framework. [Singapore] has continued to promote economic growth through an active industrial policy that targets fiscal incentives, increases public investment, promotes development of skill sets attractive to foreign investors, and focuses on economic diversification. Well-secured property rights promote entrepreneurship and productivity growth" (The Heritage Foundation).

Although rich economies grew at a higher rate than poorer countries during most of the 20th century, a shift occurred around the turn of the current millennium. Beginning in 2000, 76\% of the countries classified by the IMF as emerging markets "grew faster than America did across the 1980s as a whole" (Wolla, 2017) in terms of real pcGDP, adjusted for PPP. However, only $24 \%$ of these countries have kept up the momentum. Among the latecomers and promising emerging markets, Russia boasts a pcGDP (PPP) of $\$ 27,834$ while in 2018, Turkey's was $\$ 26,893$, Mexico's, $\$ 19,903$, Brazil's, $\$ 15,603$, Indonesia's, $\$ 12,377$ and India's, $\$ 7,183$. Table 7 compares the five emerging markets to rich countries' economic governance averages by subtracting each emerging country's economic governance from that of rich countries. 
Table 7: Russia, Turkey, Mexico, Brazil, Indonesia and India-Economic Governance

\section{Comparative Analysis}

\begin{tabular}{|c|c|c|c|c|c|c|c|c|c|c|c|c|}
\hline \\
\hline Country Name & $\begin{array}{l}\text { Prop- } \\
\text { erty } \\
\text { Rights }\end{array}$ & $\begin{array}{l}\text { Judicial } \\
\text { Effectiv } \\
\text { e-ness }\end{array}$ & $\begin{array}{l}\text { Gov't } \\
\text { Integrity }\end{array}$ & $\begin{array}{l}\text { Tax } \\
\text { Burden }\end{array}$ & $\begin{array}{l}\text { Gov't } \\
\text { Spending }\end{array}$ & $\begin{array}{l}\text { Fiscal } \\
\text { Health }\end{array}$ & $\begin{array}{l}\text { Business } \\
\text { Freedom }\end{array}$ & $\begin{array}{l}\text { Labour } \\
\text { Freedom }\end{array}$ & $\begin{array}{l}\text { Monetary } \\
\text { Freedom }\end{array}$ & $\begin{array}{l}\text { Trade } \\
\text { Freedom }\end{array}$ & $\begin{array}{l}\text { Invest- } \\
\text { ment } \\
\text { Freedom }\end{array}$ & $\begin{array}{l}\text { Financial } \\
\text { Freedom }\end{array}$ \\
\hline $\begin{array}{l}\text { Average/Rich - } \\
\text { Brazil } \\
\text { Average/Rich - }\end{array}$ & 18.28 & 11.83 & 36.48 & -4.28 & -7.31 & 75.4 & 18.6 & 11.86 & 4.67 & 14.5 & 27.38 & 16.6 \\
\hline $\begin{array}{l}\text { India } \\
\text { Average/Rich - }\end{array}$ & 18.28 & 1.93 & 16.78 & -13.18 & -29.4 & 66.6 & 19.4 & 21.96 & 7.77 & 11.1 & 37.38 & 26.6 \\
\hline $\begin{array}{l}\text { Indonesia } \\
\text { Average/Rich - }\end{array}$ & 23.38 & 10.03 & 25.08 & -17.48 & -43.5 & -6.85 & 7.2 & 14.46 & 2.77 & 3.74 & 32.38 & 6.59 \\
\hline $\begin{array}{l}\text { Mexico } \\
\text { Average/Rich - }\end{array}$ & 16.48 & 28.63 & 38.28 & -9.58 & -30.3 & -1.95 & 8.7 & 5.16 & 4.27 & 2.14 & 2.38 & 6.59 \\
\hline $\begin{array}{l}\text { Russia } \\
\text { Average/Rich - }\end{array}$ & 23.18 & 18.43 & 27.98 & -23.18 & -14.4 & -5.35 & -1.9 & 11.26 & 15.1 & 5.74 & 47.38 & 36.6 \\
\hline Turkey & 19.78 & 13.73 & 23.38 & -10.18 & -17.2 & -11 & 10.5 & 14.56 & 10.2 & 3.94 & 7.38 & 6.59 \\
\hline
\end{tabular}

In terms of property rights, Indonesia and Russia display the greatest differences at $23.38 \%$ and $23.18 \%$ respectively, whereas the highest score for differences in judicial system effectiveness goes to Mexico at 28.63\%. The lowest percentages in government integrity scores were recorded by Mexico and Brazil, at 38.28\% and 36.48\% respectively, followed by Russia at 27.98\%. All five emerging markets imposed excessive tax burdens on citizens, with Russia taking the lead with $-23.18 \%$, followed by Indonesia with $-17.48 \%$. In addition they all spent in excess, i.e. $43.5 \%$ by Indonesia, $-30.3 \%$ by Mexico and $-29.4 \%$ by India. ${ }^{16}$ Brazil and India demonstrate the greatest deterioration in fiscal health, at $75.4 \%$ and $66.6 \%$ respectively. India and Brazil placed strict limits on business freedoms, with scores of $19.4 \%$ and $18.6 \%$ respectively. India had more problems with labour freedom, Russia and Turkey with monetary freedom, and Brazil and India with trade and financial freedoms. Lastly, Russia, India, Indonesia and Brazil faced serious problems with investment freedom, with respective scores of $47.38 \%, 37.38 \%, 32.38 \%$ and $27.38 \%$.

Figure 3 contrasts the economic governance performance of the five emerging countries with the averages of wealthy countries and East Asian nations.

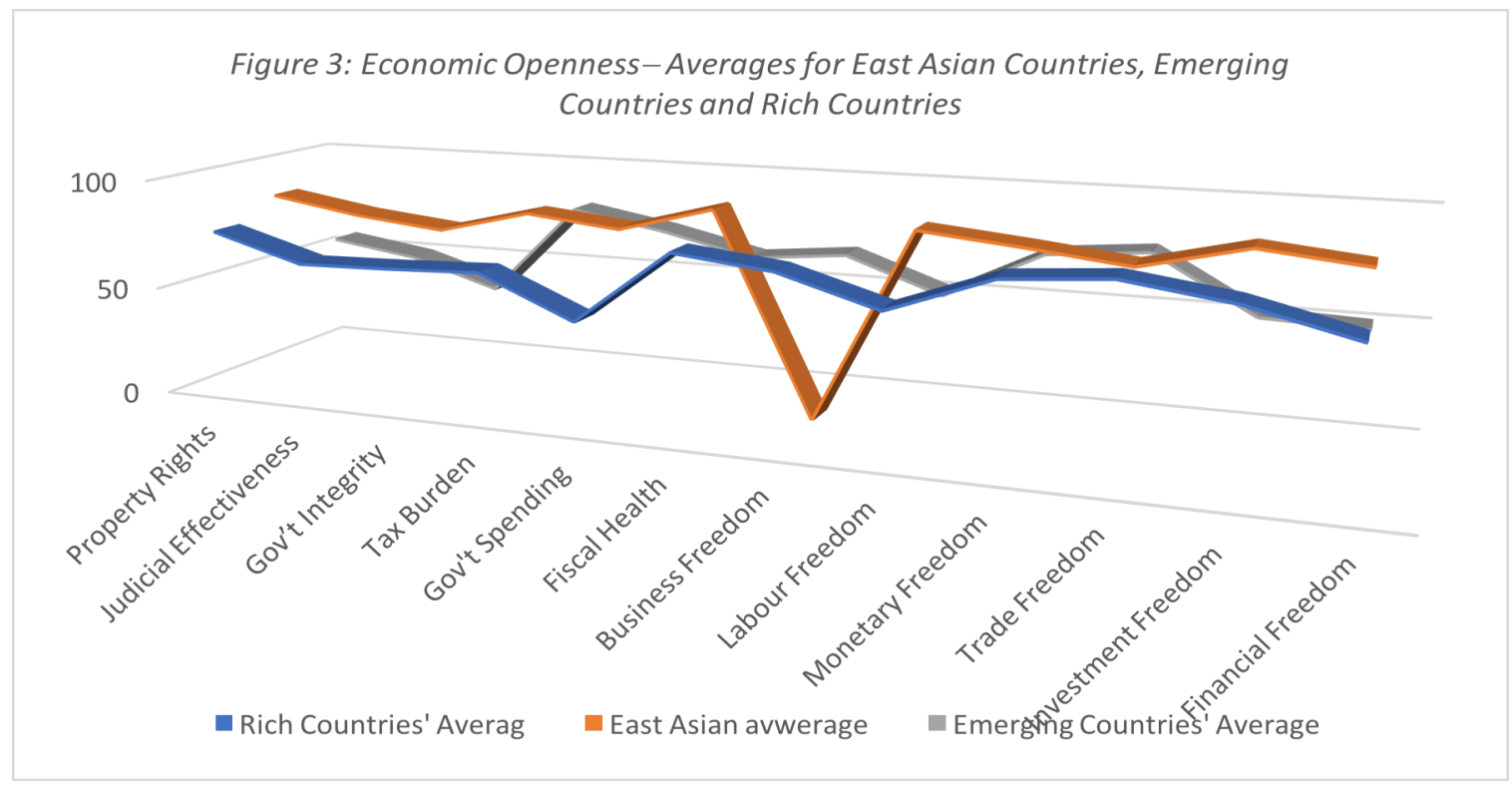

\footnotetext{
16 Advanced economies have larger balance sheets compared to emerging markets and low-income developing countries. This reflects the size of their public sectors, which generally provide more infrastructure and services. But advanced economies also have larger liabilities and, on average, lower net worth (Harris et al., 2019).
} 
"Economic growth accelerated in more than half the world's nations in both 2017 and 2018. Developed economies expanded at a steady pace of 2.2 percent in both years, and growth rates in many countries have risen close to their potential, while unemployment rates in several developed economies have dropped to historical lows" (United Nations, 2019). East Asian countries are performing even better, but many developing economies are falling behind, Delays in emerging nations joining East Asian and rich countries may be explained in part by their poor economic governance performance. Indeed, as shown in Figure 3 comparing the five emerging countries' average economic governance performance to rich country and East Asian averages, the five emerging countries consistently lag behind the average performance of rich countries and even further behind the average for the countries of East Asia, at every level of economic governance, except for government spending. Further, emerging countries do not seem to be convinced that WMS is fundamentally a function of the quality of economic governance and that wealth can be improved merely by increasing incomes within the labour force. They would do well to understand that overall, human capital can account for up to two thirds of the wealth of nations (Lange et al., 2018).

The results of this paper combined with information on the experiences of Singapore and other East Asian economies make it possible to sketch a rough WMS model. An economy seeking to increase and sustain wealth must fulfill specific requirements of the 12 components of economic governance. It must guarantee its citizens respect of their property rights by having in place a fair legal framework that allows free accumulation of private ownership. Such legal framework should be backed up by clear, effective ${ }^{17}$ and enforced laws. Indeed, only wellfunctioning legal frameworks can make citizens feel protected against the unlawful actions of others, including government and powerful private parties. Governments that are wealth seekers must subjugate the evil of corruption that poses a constant and serious threat to the effectiveness of institutions and public decision making ${ }^{18}$ as they work to achieve their WMS goals. They must be credible regarding their integrity because lack thereof reduces economic vitality, increases costs and shifts resources to unproductive lobbying activities, while setting unfair tax burdens on citizens. These governments must also secure fiscal health, because its absence inevitably leads to public finance erosion, ${ }^{19}$ which in turn leads to macroeconomic instability and economic uncertainty. Governments must opt for optimal government size, which curbs spending, and exercise discipline regarding the national budget. Such discipline should cover not only consumption, but also all transfer payments related to various entitlement programs. An economy seeking wealth creation and sustainability should also ensure open market conditions within its economic environment by establishing and protecting freedom in business and financial affairs. This can be achieved by setting appropriate conditions and taking rational measures that encourage exchange and investment within regulatory and infrastructure environments. Freedom must also be ensured within all areas of development - in labour, by acting on various aspects of the legal and regulatory frameworks of the labour market, and in monetary policy, by combining measures of price stability with an assessment of price controls. Both inflation and price controls distort market activity. Freedoms in other areas of development include trade, through minimizing tariff and non-tariff barriers that affect imports and exports of goods and services; investment, by lifting constraints on the flow of investment capital; and the financial sector, through measures that remove banking efficiency and independence from public control and interference.

\footnotetext{
17 Judicial effectiveness requires efficient and fair judicial systems to ensure that laws are fully respected, with appropriate legal actions taken against violations.

18 Bribery, patronage and the like.

19 Fiscal health plays an important role in economic freedom. Growing deficits and debt burdens are caused by poor government budget management,
} 
In the past two decades or so, some emerging economies have demonstrated with considerable success that it is possible to catch up economically with rich countries and even surpass them; this is called convergence. For instance, by investing more in economic governance, emerging markets can ensure that the successful trends they have achieved do not reverse and turn to divergence. Concurrently, they must keep in mind that "open markets offer the only realistic hope of pulling billions of people in developing countries out of abject poverty, while sustaining prosperity in the industralised world" (Kofi Annan). There is always the risk that focusing on wealth alone may lead these countries to miss the mark. In countries where an appropriate institutional environment is lacking, WMS will remain elusive (Powell, 2019). Countries economically growing at a robust pace and within the boundaries of sound economic governance can expand their pool of resources, providing them with a solid foundation to convert wealth into wellbeing. Successful WMS seems to indicate that economic governance alone does not provide a complete picture of wealth creation; in some cases, other factors like government engagement and support are just as important. South Korea and China are perfect examples of countries in which government-led initiatives have been imposed (Wolla, 2017). Countries like Luxembourg and Ireland, for instance, made their way to wealth by having sophisticated financial sectors and tax regimes that helped attract foreign investments and professional talent. Other economies like Canada, Norway, Qatar and Kuwait use their large reserves of hydrocarbons or other lucrative natural resources to shore up their wealth (Ventura, 2019).

\section{CONCLUSION}

Given experiences from emerging markets, this paper invites consideration of the critical role of economic governance in wealth creation. Such invitation is reinforced today by world globalization, which may be transforming the planet with positive sum economic growth and wealth creation and giving more people access to greater wealth (Roser, 2019). Only nations that adopt the appropriate attitude toward economic governance can take part in this wealth race. The WMS process may be compared to a game of Scrabble (Pritchett, 1997): "Countries that have a greater variety and flexibility of capabilities can make more diverse and complex goods, just as a Scrabble player who has more letters can generate more and longer words." 20 The dark period of colonialism may have prompted some economies to engage in development while delaying others, but the development game remains unchanged. Countries that have developed seem to have a specific behaviour that affects every single aspect of their economic activity, such as strong government engagement, clear development objectives, low levels of corruption, good public education and training, budget discipline, a fair judicial system, etc. in short, an open economy. This paper has presented the components of economic governance and explained their relation to wealth creation and sustainment. It also warns countries whose good fortune has already made them rich not to depart from these principles. Indeed, economic governance creates businesses, businesses create jobs, and citizens with jobs create wealth, whereas weakness in economic governance does the reverse.

For citizens of a nation, the good luck of the birth place seems to drive wealth accumulation (Roser, 2019b), the sustainability of such wealth seems, however, to be dependent of the economic governance of its rulers.

\section{References}

Credit Suisse (2018), "Global Wealth Report”. https://www.credit-suisse.com/about-us/en/reportsresearch/global-wealth-report.html.

20 Goods and services are made by stringing together productive capabilities - inputs, technologies, and tasks - just as words are made by putting letters together. 
Gaspar V. J. Harris, and A.Tieman (2018), "The Wealth of Nations: Governments Can Better Manage What They Own and Owe". IMF Blog. At: https://blogs.imf.org/2018/10/09/the-wealth-of-nations-governments-can-bettermanage-what-they-own-and-owe/

Gentilini, U., G. M. Grosh, J. Rigolini, and R. Yemtsov (2020). “Exploring Universal Basic Income: A Guide to Navigating Concepts, Evidence, and Practices." Overview booklet. World Bank, Washington, DC.

http://blogs.worldbank.org/opendata/new-country-classifications-income-level-2019-2020.

Globalist. (2011), "Kofi Annan on Global Futures." February 6; https://www.theglobalist.com/kofi-annan-onglobal-futures/.

Harris J, A. Senhadji, and A. F. Tieman (2019), “A Global Picture of Public Wealth”. IMF blog. At : https://blogs.imf.org/2019/06/18/a-global-picture-of-public-wealth/

The Heritage Foundation and The Wall Street Journal (2018), "Index of Economic Freedom (IEF). https://www.heritage.org/index/download\#

Islam, R., M. McGillivray (2019), "Wealth inequality, governance and economic growth" Economic Modelling. https://doi.org/10.1016/j.econmod.2019.06.017

Koukoulas S. (2015), Economic growth more likely when wealth distributed to poor instead of the rich". The Guardian, https://www.theguardian.com/business/2015/jun/04/better-economic-growth-when-wealthdistributed-to-poor-instead-of-rich.

Lange, G.M., W. Quentin; and K. Carey (2018), "The Changing Wealth of Nations: Building a Sustainable Future". Washington, DC: World Bank. @ World Bank. https://openknowledge.worldbank.org/handle/10986/29001 License: CC BY 3.0 IGO."

Morck, D., A. Stangeland, and B. Yeung (1998), "Inherited Wealth, Corporate Control, and Economic Growth the Canadian Disease? Randall K. https://www.nber.org/chapters/c9014.pdf

Naciri. A. (2018). «The Governance Structures of the Bretton Woods Financial Institutions - A Case of "BeggarThy-Neighbour". Springer. New York (2018). At : https://www.amazon.com/dp/3319979051

Powell B. (2019), "Making Poor Nations Rich Entrepreneurship and the Process of Economic Development". Stanford University Press.

Pritchett, L. (1997) “Divergence, Big Time.”, The Journal of Economic Perspectives, Vol. 11, No. 3 Summer, pp. 317 Published by: American Economic Association).

Roser M. (2019a) “Which countries achieved economic growth? And why does it matter?”. At: https://ourworldindata.org/economic-growth-since-1950

Roser, M. (2019b) - "Global Economic Inequality". Published online at OurWorldInData.org. Retrieved from: 'https://ourworldindata.org/global-economic-inequality'.

Standing G. (2017), "Basic Income: A Guide for the Open-Minded”, Yale University Press.

Stern, A. (2016). "Raising the Floor: How a Universal Basic Income Can Renew Our Economy and Rebuild the American Dream". New York: Public Affairs.

United Nations (2019), "The World Economic Situation and Prospects". https://www.un.org/development/desa/dpad/wp-content/uploads/sites/45/WESP2019_BOOK-web.pdf

Ventura, L. (2019), "Richest Countries in the World 2019". IMFblog. At: https://www.gfmag.com/globaldata/economic-data/richest-countries-in-the-world

Wolla, S. (2017), “Why Are Some Countries Rich and Other Poor?" Page one economics. At:

https://research.stlouisfed.org/publications/page1-econ/2017/09/01/why-are-some-countries-rich-and-otherspoor/

https://openknowledge.worldbank.org/handle/10986/22553 License: CC BY 3.0 IGO."

World Bank (2015). “The Little Data Book on Financial Development 2015/2016”. Washington. DC. World Bank. At: http://www.worldbank.org/en/publication/wdr2017. Accessed 10 January. 2018.

World Bank (2017). "World Development Report. Governance and the Law".

The World Factbook. At: https://ourworldindata.org/economic-growth-since-1950

https://knoema.fr/pjeqzh/gdp-per-capita-by-country-statistics-from-imf-World Bank Human Capital Index 


Australia
Austria
Belgium
Croatia
Chile
Cyprus
Czech Republic
Denmark
Estonia
Finland

APPENDIX A: SAMPLE COUNTRIES

$\begin{array}{lll}\text { France } & \text { Latvia } & \text { Slovakia } \\ \text { Germany } & \text { Lithuania } & \text { Slovenia } \\ \text { Greece } & \text { Luxembourg } & \text { Spain } \\ \text { China } & \text { Malta } & \text { Sweden } \\ \text { Hungary } & \text { Netherlands } & \text { Switzerland } \\ \text { Ireland } & \text { New Zealand } & \text { Taiwan } \\ \text { Israel } & \text { Norway } & \text { Trinidad and Tobago } \\ \text { Italy } & \text { Poland } & \text { United Kingdom } \\ \text { Japan } & \text { Portugal } & \text { United States } \\ \text { Korea, South } & \text { Singapore } & \text { Uruguay }\end{array}$

